\title{
South African
}

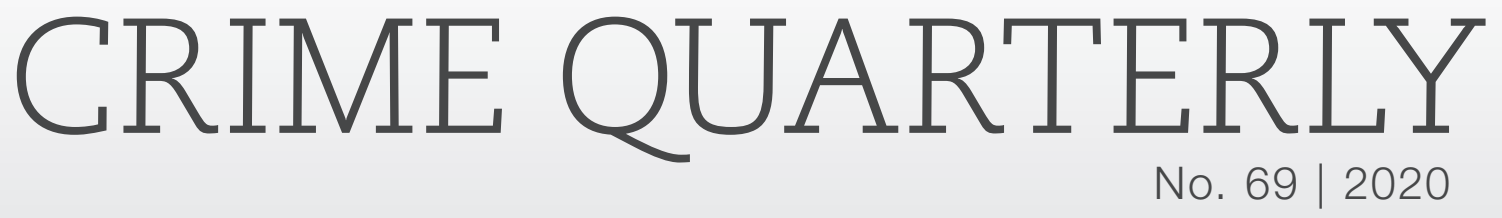

\section{Comment and analysis}

\section{The crisis of criminal justice in South Africa}

\section{Edwin Cameron ${ }^{1}$}

cameron.edwin@gmail.com

http://dx.doi.org/10.17159/2413-3108/2020/i69a9253

In 2017, I delivered a lecture at the University of the Western Cape (UWC) aimed at confronting a controversial and often overlooked crisis in the criminal justice system - the minimum sentencing regime. ${ }^{2}$ While writing that lecture, which forms the basis of this article, I originally entitled it 'Crisis? What Crisis? Why Criminal Justice is Failing All in South Africa'. Shortly after that, the tragedy of Uyinene Mrwetyana's death hit South Africa. The anguish of a vulnerable woman at the very University where the lecture was to be delivered having her life brutally ended, in unspeakably nightmarish moments, by the exertion over her of ghastly destructive male dominance, shocked us all to the core. It elicited a national outpouring of grief and rage - and, rightfully, a new demand for answers from our criminal justice system. A whimsical title no longer seemed appropriate. Things are too deadly - deathly - serious.

I do not suggest that criminals, especially those that are violent against women, do not deserve harsh punishments. My central thesis is that minimum sentences are no response at all to curbing crime in South Africa and to making our people - vulnerable young people like Uyinene - safe. The minimum sentencing regime is a misdirected, hugely costly and above all ineffective way of punishing criminals and dealing with crime. It has been an extravagant mistake of science, understanding, and policy and social response.

In this article, I summarise some of the arguments from that lecture and consider 
why we are still stuck with minimum sentences when they are demonstrably useless and counterproductive. I find the reasons in our broken history, in incoherent decision-making in our present politica leadership, institutional incompetence, and the fact that minimum sentences themselves, through their false promise, divert us from finding more efficient solutions.

\section{How we got minimum sentences}

During apartheid, prisons were referred to as 'universities of crimes' or 'criminal headquarters'. ${ }^{3}$ The prison system, based on the Prisons Act 8 of 1959, was strictly segregated racially. ${ }^{4}$ The death penalty was regularly enforced - at its height, more than three times a week, in Pretoria. Before apartheid officially ended, South Africa reconsidered its approach to crime and punishment, viewing prisoners as more entitled to human rights. A transition from a punitive to a restorative justice approach was heralded by the change in mandate, legislation, and policies towards prisoners. Prison services were relocated from the Department of Justice and renamed the Department of Correctional Services. ${ }^{6}$

The rights enshrined in the interim Constitution and then in the Constitution's Bill of Rights embodied this transformation. It was vividly encapsulated the newly established South African Human Rights Commission's Report, produced in 1998, following an inquiry into prisons in South Africa. ${ }^{7}$ In the Foreword, the Commission's chairperson, Professor Barney Pityana, stated optimistically that the duty of the Commission is 'to develop a different calibre of prison system that would be consistent with our new Constitution and with international norms and standards'.

In the same spirit, the Constitution provides that prisoners, including both remand detainees and sentenced offenders, have the right to conditions of detention that are consistent with human dignity'. ${ }^{9}$ This provision requires that, at a minimum, prisoners should have access to exercise, adequate accommodation, nutrition, reading material and medical treatment. The Constitution also seeks to protect inmates from cruel, inhuman or degrading treatment or punishment. Many of the new leaders of democratic South Africa had experien prison or the real threat of it. The new President, Nelson Rolihlahla Mandela, had served 27 years in apartheid's prisons.

The upward-looking approach to penal conditions was premised on the supposition that high crime rates were caused by apartheid. ${ }^{10}$ Once apartheid was abolished the crime rate would gradually decline and the little crime remaining would be dealt with by a fai criminal justice system.

Reality proved to seem the opposite. During the first decade of democracy, crime increased - as did fear of crime. According to the South African Police Services (SAPS), during 19942004 , crime in fact increased by an alarming $30 \% .{ }^{11}$ Our country experienced what was described as a post-apartheid 'crime wave', ${ }_{12}$ The National Victims of Crime Survey of 2003 concluded that the fear of crime amongst South Africans more than doubled - from 25\% in 1998 to $58 \%$ in 2003. ${ }^{13}$ The majority of South Africans, black and white, rich and poor, urban and rural, felt unsafe in the newly democratic state.

This inevitably generated public calls for criminals to receive longer and tougher sentences. ${ }^{14}$ This triggered 'tough on crime' policies, which were harsh and punitive..$^{15} \mathrm{~A}$ statement by the Commissioner of Correctiona Services, Khulekani Sithole, in 1997 illustrates a relapse to a punitive approach: '[t]hey are animals. They must never see the sunlight again'. ${ }^{16}$ The Minister of Safety and Security in 1999, Steve Tshwete, claimed that 'the criminals have obviously declared war against the South African public... we are ready more than ever before, not just to send the message to the criminals out there about our intentio but more importantly to make them feel that the tyd vir speletjies is nou verby' [the time for games is now over]. ${ }^{17}$

\section{The radical shift}

The harsh new policies adopted during the late 1990s included:

- the Criminal Law Amendment Act 105 of 1997, which introduced minimum sentencing provisions;

- the Criminal Procedure Amendment Acts of 1995 and 1997, which made getting bail lot tougher; ${ }^{18}$

- the Correctional Services Act 111 of 1998 which complicates release processes and stiffens bail and parole processes; and

- the Prevention of Organised Crime Act 121 of 1998 which in effect casted a wider criminal net and ordered the forfeiture of criminal gains. ${ }^{19}$

In addition, the United States model of supermaximum security prisons was imported into South Africa in the form of C-Max prisons. ${ }^{20}$

The most puzzling and perhaps the most harmful of these were the minimum sentencing prescripts. As Lukas Muntingh notes, '[t]hese changes were purposefully directed at imposing harsher punishments by limiting access to bail, increasing sentence jurisdiction, lengthening prison terms, limiting courts' discretion at sentencing and increasing non-parole periods. However, the impact of these measures, individually or combined, on the already overcrowded prisons was of little concern to the legislature and the executive' ${ }^{21}$

The findings of the sadly now-forgotten Jali Commission underscored all this. It found that [t]he relatively new bail laws, which limit the circumstances under which an accused person can be released on bail, certainly contribute o the high number of accused persons languishing in the awaiting trial section of ou Prisons. Furthermore, the renewed minimum sentence legislation also impacts negatively in that many prisoners who have been convicted in the regional courts on serious charges have to wait extraordinarily long periods for High Court dates before they are sentenced'. ${ }^{22}$

\section{The minimum sentencing regime}

Minimum sentencing legislation in South Africa dates back to the 1970s. In 1971 the apartheid ideologue Dr Connie Mulder introduced minimum sentencing for cannabis and other drug-related offences. ${ }^{23}$ Those sentences had an appalling impact and conspicuously failed to curb the use and distribution of cannabis.

Even the apartheid judiciary condemned them. ${ }^{24}$ They did so even against minimum sentences in political (that is, anti-apartheid) cases. ${ }^{25}$

My first experience of the impact of minimum sentences was when I visited Vereeniging prison, in July 1976, as a vacation-break registrar to Judge Douglas Davidson, a judge of the then-Transvaal Provincial Division of the Supreme Court, who was on circuit court. We found a prison crammed full of women and men, most of whose only sin was to possess or pass on small amounts of cannabis something the indigenous populations of this country had been doing for centuries.

Just a year before the enactment of the 1997 statute, the new Minister of Justice, Dullah Omar had appointed a committee of the South African Law Reform Commission (SALRC) to consider the sentencing policy. The Commission's report set out six alternatives to minimum sentencing. ${ }^{26}$ These included more sensible, just measures such as presumptive sentencing guidelines, voluntary sentencing 
guidelines, and legislative guidelines. ${ }^{27}$ Presciently, it also cautioned that, although too early to gauge long-term effects, the new sentences would likely have a 'profound' effect on the prison population. ${ }^{28}$ But in reaction to the crime panic, the country's lawmakers had already shut the door. Parliament had selected the harshest option - without the benefit of mature law reform deliberative process.

The Criminal Law Amendment Act strictly curtailed the power of judges to determine the length of prison terms for offences or offenders. Instead, it provided minimum sentences for certain serious offenses. These included a mandatory life sentence for:

- premeditated murder

- murder of a law enforcement official, or a potential state witness:

- murder connected to a rape or robbery with aggravated circumstances:

- rape committed more than once by the accused or others;

- gang rape; and

- rape of a minor under $16 .{ }^{29}$

The law mandates a 15-year sentence for a first-time offender convicted of murder (under circumstances that would not otherwise merit a life sentence), robbery, certain drug-related offenses, weapons-related offenses, or '[a]ny offence relating to exchange control, extortion, fraud, forgery, uttering, theft'. A repeat offender must be sentenced to not fewer than 20 years, and a third- or further-time offender a sentence of not fewer than 25 years. In addition, the minimum sentences cannot be suspended. ${ }^{30}$ Time spent awaiting trial cannot be counted as part of the sentence to be served. ${ }^{31}$

The new minimum sentencing regime was intended to be a temporary solution to a temporary problem. ${ }^{32}$ Minister Omar told parliament that the new sentences were 'to tide us over our transition period'33 and to 'restore confidence in the ability of the crimina justice system to protect the public against crime'. ${ }^{34}$ They were initially stated to apply for a limited period of two years only, which could be extended from time to time. ${ }^{35}$ However, following the amendments made in 2007 it is now in force until expressly scrapped. ${ }^{36}$

Consistency in sentencing is supposedly one of the primary justifications for minimum sentences. ${ }^{37}$ Judges may depart from minimum sentences only if 'satisfied that substantial and compelling circumstances exist which justify the imposition of a lesser sentence', ${ }^{38}$ However, this criterion is unclear and inconsistently applied. ${ }^{39}$ Factors used, erroneously, to justify lesser sentences have included: the previous sexual history of the complainant, an accused's cultural beliefs about sexual assault, absence of excessive force in perpetrating the rape, lack or apparent lack of physical harm to the complainant, lack or apparent lack of psychological harm to the complainant, any relationship between the accused and the complainant before the offence (including a consensual sexual relationship) and a lack of education, sophistication or disadvantaged background on the part of the accused. ${ }^{40}$ In determining the appropriate, proportionate and justified punishment, the minimum sentencing regime, even with its qualification of 'substantial and compelling circumstances' is sometimes utterly misdirected.

\section{The consequences}

The increases in carceral lengths has meant a significant increase in the prison population. At the time of the lecture (because of COVIDrelated interventions, the number has thankfully declined), there were about 164129 prisoners in South Africa - 46260 remand detainees and 117869 sentenced offenders. ${ }^{41}$ By contrast, in 1995 the total prison population was 112572 (27 320 remand detainees and
85252 sentenced offenders). ${ }^{42}$ This means that over just less than a quarter-century, our prison population increased by two-fifths (39\% or $1.4 \%$ per annum). Even though this is not as high as the peak prison population numbers in the early 2000s, the Judicial Inspectorate of Correctional Services ${ }^{43}$ has described the current numbers as 'unacceptably high'. ${ }^{44}$

Together with the abolition of the death penalty by decision of the Constitutional Court in 1995, ${ }^{45}$ which led to the imposition of life sentences on most of those previously sentenced to death, ${ }^{46}$ and restrictions on parole policies, minimum sentencing has resulted in gross overcrowding. ${ }^{47}$ This not only negatively affects the well-being of prisoners, but also impedes good governance and administration of a prison. ${ }^{48}$

\section{The human impact}

Prisoners in South Africa experience a number of day-to-day perils. Sexual violence seems to be pervasive. Violence in general is rampant in South African prisons, perpetrated by prisoners (whether within or outside gang structures). ${ }^{49}$ Prisons are known as sites for the spread of communicable and infectious diseases such as sexually transmitted diseases, TB and HIV. Mental health is also a serious problem. Prisoners with mental issues are not detected when entering the system and remain incarcerated in communal cells. Conditions in the prison setting are traumatic and trigger mental issues. Mental health problems are also prevalent among prisoners re-entering society who face the stigma and marginalisation within their communities. And, perhaps most frighteningly, gangs and drugs flourish in overcrowded prisons.

In 2015, I visited Pollsmoor Correctional Centre (Remand Centre and Women's

Centre). My later report indicated that 'the extent of overcrowding, unsanitary conditions, sickness, emaciated physical appearance of the detainees, and overall deplorable living conditions was profoundly disturbing'. ${ }^{50} \mathrm{My}$ report exposed that overcrowding was evident everywhere, but especially in the Remand Detention Facility where occupation was at a startling 300\%, with an average of 65 prisoners per cell (sharing one toilet and one shower). In response to the report, Sonke Gende Justice and Lawyers for Human Rights brought proceedings in the Western Cape High Court, seeking a structural interdict to address these conditions. As a result, the Department of Correctional Services transferred a significant number of prisoners from Pollsmoor to other centres. But, grievously, this seems merely to have transferred the problem elsewhere. The current Judicial Inspector of Correctional Services, retired Justice Johann van der Westhuizen, noted that 'although [the court order] alleviated the overcrowding crisis at Pollsmoor, it caused other unintended challenges, for example, exacerbating overcrowding elsewhere, especially at smaller centres'. ${ }^{51}$ He cautions that overcrowding in the Western Cape is still at $90 \%$ or more..$^{52}$

The 164129 individuals incarcerated are not necessarily constantly behind bars and out of the public domain. The South African prison population is particularly fluid with one of the highest incarceration rates in the world coupled with one of the highest recidivism rates in the world (estimates range from 60-90\%). ${ }^{53}$

These indicators show that there is a constant interchange between people inside and outside of prisons. Our prison walls are permeable. Former Inspecting Judge Hannes Fagan ${ }^{54}$ warned that the harsh conditions created in the prisons because of overcrowding are 'not curbing crime' - on the contrary, they are 'creating it'. 55

Minimum sentences in fact have a pernicious effect - on our correctional system, on 
offenders, and, most of all, on us - our society. The reason is that minimum sentences offer us a false promise - the belief that we are actually doing something about crime. But in fact we are not. And this false promise lets those who are responsible for effectively dealing with crime - our society's leaders, and the criminal justice system for whose functioning they are responsible - off the hook.

To make my point during the UWC lecture, I considered four possible justifications for minimum sentences: (i) prison deters crime, (ii) imprisonment incapacitates criminals and prevents more crime while they are in prison,

(iii) prison can rehabilitate criminals, and (iv) finally, prison is retributive and so vindicates justice for victims and society. None of these justifications supports minimum sentencing as applied in South Africa today. The blunt fact is that minimum sentences simply do not work. What is more, they have seriously and dangerously clogged up our prison system.

\section{Why no response?}

After the UWC lecture, I anticipated public outrage. After all, a judge had decried minimum sentences. Surely pro-imprisonment activists, rightly concerned about women and other victims of crime, would speak out to rebut my arguments against harsh sentencing? But no. Not a peep. ${ }^{56}$ In the United States - from where minimum sentences originate, and which provided specifically the model for our statutory format - an engrossing, bipartisan debate has been taking place about incarceration, about its racial impact and about its social utility and costs. ${ }^{57}$

In my vanity, or naiveté, I had hoped to help trigger a similar debate here. It has not happened. Apart from courageous nongovernmental organisations, including Sonke Gender Justice, Lawyers for Human Rights, Just Detention International, Wits Justice
Project and others combined in the Detention Justice Forum, ${ }^{58}$ who continue the fight for rationality in penal and criminal policy, there has been silence.

There are four possible explanations. First, South Africans are deeply worried about crime, and justifiably so. ${ }^{59}$ With crime rampant, locking up criminals and throwing away the key are favourably considered because of a sense of bewildermen, bafflement and fear about crime. Some people even propose reintroducing the death penalty. ${ }^{60}$ Our dismay, fear and anger at the horrors criminals inflict on us paralyse us. They prevent us seeking better and more effective solutions.

Second, the slowdown of our economy has been a preoccupation and distraction. Our economic woes, combined with the paralysis from crime divert us from proper criminological and penological solutions. The economic situation has led to joblessness; our unemployment rate for the first quarter of 2019 was $27.6 \%$ (with a particular increase in youth unemployment at a startling 55.2\%). ${ }^{61}$ As a result, many turn to crime. ${ }^{62}$ With resources scarce and times austere, it is difficult to argue for more resources for prisoners or more resources for effective crime prevention. Budgetary needs compete with needs in health and education and housing.

Third, crime is politicised in South Africa. With the scars of our apartheid past, our prison population was and still does comprise mainly black males. ${ }^{63}$ The issue today is not just race but also class. The majority of South African prisoners, sentenced and remand detainees, are from poor disadvantaged backgrounds. ${ }^{64}$ Moreover, the burden of serious crime is disproportionately borne by poor black South Africans. ${ }^{65}$ Poverty often means a matching voicelessness. The families of rapists and murderers sentenced to life imprisonment would form an improbable lobby group for penological reform. Let me be blunt. Our new democratic elite, including me as a retired Judge and almost everyone who attended my lecture or is likely to read this article, cares too little for reasons of race and class. Our lack of caring means that we fail to see the urgent need for constructive thought and action to implement solutions.

The fourth explanation for the lack of response is that nine years of criminal syndicalism and looting of state assets has sapped moral energy and institutional capacity. The crime surge in democratic South Africa was directly linked to the collapse of institutional capacity in the police - particularly, the crime detection and follow up services - and the collapse of competence in the National Prosecuting Authority (NPA). This breakdown became sharply aggravated during the 'Zuma years'. Former President Zuma seemed determined to appoint as head of the NPA a loyalist who could be relied upon to protect his own interests. This lead to a chaotic series of leadership bungles attributable to malign incompetence of various kinds. ${ }^{66}$ The result has been a catastrophic loss of focus and capacity. Over the period preceding the Ramaphosa presidency, our government has been (and unavoidably still is) plagued by criminally syndicated corruption and institutional disintegration.

\section{Possible solutions}

There are solutions. They are not easy. None of them offers a quick fix. The major response to the crime wave in our country should be to recognise that the sole inhibiting institutional response to criminal conduct is the certainty of detection, the certainty follow up, the certainty of arraignment, the certainty of prosecution - and the certainty of punishment. In this certainty, the length of sentence plays no role. In other words, whether a potential rapist faces a sentence of 2, 5, 10 years or life, it is not the length of sentence but the certainty of sentencing that will make them stop. This means that we must look away from minimum sentences.

The blunt point is this. We do no good at all by finding and prosecuting a haphazardly small segment of rapists and murderers and sentencing them to life imprisonment, jamming our prisons. What possible point is there to this in a country with 21022 murders a year and with reportedly over 41583 rapes a year?67 Minimum sentences merely divert us from understanding what we should be doing.

Jameelah Omar underscores that law alone can only go so far: 'bringing back the death penalty, full life sentences for those convicted of sexual offences ... are not solutions. Our criminal justice system is flawed, in some ways fatally defective, and needs to be overhauled'. ${ }^{68}$ What we should be doing is the long slow process of improving police capacity. This doesn't necessarily mean increasing numbers, but police competence, responsiveness, training and skills. It should also include restoring crime intelligence, which could lead to the responsiveness and turnover of the NPA.

In the meantime there are some things we can and have to do. First, abolish minimum sentences. Scrap minimum sentences immediately for most low-level, nonviolent, or non-serious crimes. This is particularly important for drug-related offenses mandatory minimums should be eliminated. The Constitutional Court's judgment in Minister of Justice and Constitutional Development v Prince $^{69}$ is a step in the right direction. The Constitutional Court ruled, unanimously, that criminalising the use or possession in private, or cultivation in a private place, of cannabis by an adult for his or her own personal consumption in private, violates the privacy guarantee of Bill of Rights. A significant consideration the court took into account was the impact of the criminal law. ${ }^{70}$ 
The 'war on drugs' is a hugely expensive and almost entirely pointless waste of lives and resources. ${ }^{71}$ More suitable punishments for nonviolent drug-related offences include: shorter sentences, probation, community service, electronic monitoring, or medical treatment. I do not mean that we should take a soft line on white-collar criminals. The fact is that minimum sentences unfairly exempt those at the top end of the criminal food chain, and unfairly impact on the poor and the dispossessed. For instance, under the current system of minimum sentencing, the same sentence applies for drug trafficking as for murder. Unnecessarily harsh sentencing should be reviewed and replaced. It is important to ensure proportionality between the various types of crime.

Second, parliament should consider implementing a Sentencing Council to reform or replace mandatory minimum sentences. ${ }^{72}$ This body would be tasked with developing and reviewing sentencing guidelines. SALRC recommended a break from the common law divergent sentencing and advocated for sentencing principles to be clearly articulated in legislation. This would be supplemented by sentencing guidelines developed by an independent Sentencing Council for a particular category or sub-category of an offence. Judicial officers are encouraged to play a key role on the council to ensure its independence and to help with institutional knowledge and practical experience. The guidelines established by the council ought to be flexible to ensure departure in appropriate circumstances. Comparable jurisdictions use a sentencing council. ${ }^{73}$ Our parliament has yet to take this up.

What is needed is a cooperative approach to reform sentencing. In order for any sentencing reform to make an impact, it requires all three branches of government to cooperate and work together to form an effective criminal justice system.

\section{Bail reform}

We need to make bail better, more efficient and more just. Bail should be available on a more flexible basis and not tie accused individuals up in rigid knots. The apartheid system notoriously used detention as a tool of coercion against those threatening the state, with detention without trial for 90 and later 180 days expressly permitted by statute. ${ }^{74}$ As a result, the Constitution provides for section $12^{75}$ and section $35(1)(f)^{76}$ of the Bill of Rights. The effect is that people in South Africa have no automatic right to bail. The rhetoric of the postapartheid 'crime wave' triggered severe criticism against bail which was blamed for the increase in crime. ${ }^{77}$ Condemnation continues to this day. On 3 March 2017, as a response to crime thenPresident Zuma requested that ministers in the security cluster review bail laws to make it more difficult to be released on bail. ${ }^{78}$ Later, it was stated that the Minister had initiated a process to review bail laws to make them stricter. ${ }^{79}$

The purpose of bail is to 'strike a balance between the interests in society (the accused should stand trial and there should be no interference with the administration of justice) and the liberty of an accused (who, pending the outcome of the trial, is presumed innocent)'. 80 What is more, as the Constitutional Court pointed out, '[b]ail serves not only the liberty interest of the accused, but the public interest by reducing the high number of awaiting-trial prisoners clogging our already over-crowded correctional system, and by reducing the number of families deprived of a breadwinner', ${ }^{81}$ Furthermore, bail is not meant to be punitive. ${ }^{82}$

However, stringent bail processes cuts both ways - it has budgetary implications for the state (and us, the taxpayers) as well as affordability problems for the individual detainee. During my recent inspection of the Johannesburg Correctional Centre, a senior official, Madondo, estimated that it costs government R330 per day (approximately R10 000 per month) to keep a single prisoner, incarcerated, whether on remand or sentenced. ${ }^{83}$ This means that cash bail in trivial amounts that an accused cannot afford is not only unjust - it is wasteful, unproductive and inefficient.

Apart from these statutory mountains, which many could not surmount, one of the biggest barriers is affordability. Even when the court is satisfied that the interests of justice permit bail, the monetary amount is set without taking the individual circumstances of the accused into account. ${ }^{84}$ The statutory provisions foresee this, and provide expressly for it. ${ }^{85}$ An authoritative survey indicated 7486 detainees were being held in detention simply because they could not afford bail. ${ }^{86}$ Of these, $76 \%$ could not afford bail of R1 000 or less. This renders them 'prisoners of poverty' - individuals not meant to be there, whose mere inability to pay the required bail amount keeps them locked in prison, where they in turn contribute to overcrowding. ${ }^{87} \mathrm{My}$ recent inspection to Johannesburg Correctional Centre revealed that there were detainees who could not afford bail of sums as small as R200 to R300. ${ }^{88}$ This is by no means a new problem. Years ago, it was exposed by Judge Fagan, when Inspecting Judge of Prisons, that at least 13000 prisoners who could not afford bail as set were being held in prison solely because of poverty. ${ }^{89}$ The denial of bail should be based on soundly-assessed danger to society, not on affordability. Bail processes are pivotal to reducing overcrowding - especially since nearly one-third (30\%) of the prison population comprises remand detainees.

In reforming our bail system, we should consider:

Adult Diversion Schemes: In New Zealand, the Police Adult Diversion Scheme involves a police diversion officer assessing the appropriateness of diversion and facilitating the signing of an agreement by the offender, which could include an apology, compensation and commitment to a restorative justice process. ${ }^{90}$

\section{Laws banning pre-trial detention under}

defined circumstances: In an effort to reduce unjust detentions, some jurisdictions prohibit remand detention for certain offences and/or potential sentences. In Armenia, an arrest (and its substitute monetary bail) can be effected only for crimes punishable by more than one year's imprisonment. ${ }^{91}$ In India, where an accused person is unable to furnish any surety for bail within a week of arrest, the accused is deemed indigent and is released on personal bond without sureties. ${ }^{92}$

Pre-trial services: Different interventions aim to ensure that an accused appears at trial and is not rearrested pre-trial. These include: court dated notifications, pretrial supervision, and risk assessments of independently verified information to assist a judicial officer in determining more equitable bail. ${ }^{93}$ In 1997, an American organisation ${ }^{94}$ established a pre-trial services project to reduce overcrowding of remand detention facilities in South Africa. Although the project was not adopted nationally, the Port Elizabeth Magistrates Court incorporated it as part of an integrated Justice System Court Centre. A review in 2001 showed a reduction in time taken to prepare a ready trial docket, improved docket quality and increased conviction rates, effective bail decisions and a reduction in remand detainees ${ }^{95}$ Although pre-trial services require more resources in an already scarce environment, savings will result from fewer detainees. This is a strategy worth revisiting.

Inquiry into the ability to pay bail: Although South African courts are required to take account of individual circumstances, particularly the financial standing of the accused, this is either not done at all, or not done on a uniform basis. There should be clear and accepted 
definitions of 'indigent' and 'ability to pay,' a standard form setting out the accused person's income, assets and other financial information and obligations, based on a certain threshold where there is a presumption about indigence or inability to pay monetary bail..$^{96}$ The SALRC recommended that fines ought to be more closely related to the means of the offender. ${ }^{97}$

Duty solicitors: ${ }^{98}$ Pre-trial detention can be reduced by providing legal services. In Nigeria, in 2004 the Police Duty Solicitors Scheme (PDSS) was launched. Newly qualified lawyers delivered free legal services for suspects at police stations. A survey in 2011 revealed the project's success - PDSS released over 10000 suspects from police stations and prisons, and nearly $80 \%$ of the releases occurred at prisons. ${ }^{99}$ With our already overburdened Legal Aid system, 'creative ideas for replicating such a duty solicitor model that take into account Legal Aid Board's financial and human resources constraints will need to be considered. The South African Legal Practice Act, for instance, may offer opportunities relating to community services'. ${ }^{100}$

For bail to be employed effectively, it must operate in a properly functioning criminal justice system. A malfunctioning criminal justice system counter-indicates the benefits of more flexible bail processes. I acknowledge fears that criminals are allowed to strike murderously again because of laxed bail processes. There are examples of a lack of proper evidence being put forward in order to properly oppose bail, which in turn results in the wrong individuals being granted bail and bound to re-offend.

Unlawful arrests, frequent police assaults, unlawful remand decisions and improper denial of bail is illustrated in the Constitutional Court decision in De Klerk $v$ Minister of Police. ${ }^{101}$ The Court emphasised 'the duty of the magistrates to apply their minds to the question of bail is of the utmost constitutional significance. Failure to discharge this duty must result in consequences for the presiding officer involved' as well as the arresting officer whose 'subjective foresight of the subsequent detention and harm' meant that the police were held liable for post-court detention.

\section{Other measures}

Besides sentencing and bail reforms, other options include releasing elderly offenders at low risk of committing violence. It is well-established that men over a certain age group have a low recidivism rate..$^{102}$ In addition, men over the age of 50 are well established to gradually become less violent. It is a safe bet that violent criminals who have grown old in prison can be released with minimal risk once they have served a just sentence. In most cases, a life sentence is an unnecessary injustice. This should be done according to individual assessment. We should also explore treatment for the mentally ill. Our prisons are not currently equipped to treat those with mental health or addiction problems. The use of super-max or isolation facilities should be approached with great caution because of their adverse impact on inmate health and mental health and because of the potential for abuses. ${ }^{103}$

We should reconsider the initial recommendations made by the SALRC. This includes a restorative justice approach that advocates for giving victims an increased role in the sentencing process. ${ }^{104}$ This is not namby-pamby thinking. The SALRC soundly considered the idea. It then proposed a new sentence of reparation. This includes elements of both restitution and compensation. The overall proposal is that the sentencing court must consider some form of reparations in every case. This may be independent or combined with other sentences and in addition imprisonment or a fine may be suspended on condition of reparations. Other procedural innovations have been designed to ensure victims have a more active role. ${ }^{105}$ In Canada, the Restorative Justice
Act was introduced in 2015 to support the use of restorative justice programs and policies. In addition, the Canadian Criminal Code promotes the use of restorative justice mechanisms (victim offender mediation programs, circles of support and accountability, peacemaking circles,

healing and sentencing circles). ${ }^{106}$ In addition, New Zealand provides for restorative justice programs through its Sentencing Act, Parole Act and Victims Rights Act. Restorative justice processes can operate at different stages in the criminal justice system. ${ }^{107}$

Finally, as Gareth Newham, of the Institute for Security Studies, recommends, we have to address the key drivers of violence. ${ }^{108}$ Since most violent behaviour is learnt at home and in communities it is imperative to invest in evidence-based interventions and programs. This includes positive parenting programs, afterschool care, anti-bullying campaigns at school as well as other initiatives to tackle the root causes of gender-based violence.

These recommendations are in line with other jurisdictions that are gradually shifting away from the minimum sentencing regime.

\section{Conclusion}

The arguments made here are not blind to the harsh realities and horrors of crime. But the fact is that our current criminal justice system's approaches to crime are so ineffective and counter-productive that we find ourselves in a frightening crisis: we are terrified of crime and yet we are trapped in our futile response. We find ourselves in a frightening vortex.

If we want to curb crime, it is in our own selfinterest to find solutions that will effectively reduce crime. The fluidity of the prison population means we must ensure that prisoners whether sentenced or awaiting trial live in conditions consistent with human dignity. It is a myth that prisons are impermeable. Prisoners are part of our society and, conversely, society seeps porously into prison. What we do to prisoners comes back to haunt us when they return to society.

We cannot condone the absence from almost all our prisons of effective training courses and other rehabilitative programs. During my visit to Devon Correctional Centre in June 2017 we discovered that a skills centre (workshop) offered welding and spray painting, taught by long-term inmates. ${ }^{109}$ However, we were informed that the Centre was short of steel and welding rods and steel paint, and that budget had run out.

In particular, we need to ensure that bail processes are effective and fair, and that they truly balance the interests of the accused against the interests of society. The point those complaining about release on bail of dangerous offenders make is well warranted and correct. It is a point about systems. Their complaint is about a misleading, misdirected and inefficient system of crime intelligence, crime detection and evidence gathering. And the anger about bail processes is justified. But what our bail processes at present are doing is to release the criminally dangerous while keeping thousands upon thousands of criminally non-dangerous incarcerated. We therefore have to introduce sharper, keener, more efficient and betterinformed bail processes.

Minimum sentencing legislation has failed us. It has created inconsistent sentencing patterns that perpetuate a 'lock up and throw the key away' mantra that does not effectively deal with reducing or deterring crime. While intended to be a temporary fix, is in no way sustainable. It is time to find more permanent solutions. Our national response to AIDS - another insidious and frightening threat to our democracy - invites comparison: not because of the viral impact but because we mishandled it so catastrophically. The same applies to crime. We should rigorously seek evidence-based solutions. Until now, we have not. As with AIDS, this 
costs us dearly. We are struggling so much to stop ourselves from drowning that we are not learning to swim. We are so stuck in our crisis that we are not seeing the solutions available to us.

But there are reasons to be optimistic. The new government is currently gradually addressing the insidious harms of criminal syndicalism, through the Zondo Commission of Inquiry into Alleged State Capture. A new and credible head of the NPA has taken office. Significantly, the new Minister of Justice and Correctional Services, Ronald Lamola concedes that the minimum sentencing legislation has contributed to the increasing prison population, which has led to overcrowding that has negatively impacted the functioning of correctional centres and the conditions for inmates in prisons. ${ }^{110}$ On gender based violence and the call to reinstate the death penalty, the spokesperson for Minister Lamola has stated that the death penalty will not deal with femicide and other forms of violence against women and children. ${ }^{111}$ In addition, recent judgments ${ }^{112}$ handed down by the Constitutional Court indicate a strong commitment to a just system and a willingness to challenge the mechanisms developed during the post-apartheid 'crime wave'.

There does appear to be political will to tackle the perils of our criminal justice system. The social, legal and political arena has changed significantly. Yet, with the current surge in crime ${ }^{113}$ we must not revert to perpetuating the pointless punitive justice rhetoric and policies. We have tried them. And they have not worked. It is imperative, and in our own interests, to consider a more restorative and rehabilitative approach to justice coupled with victim-focused measures and institution-building. And this is in line with global trends. There are no simple quick solutions.

To comment on this article visit

\section{Notes}

Edwin Cameron is a former Justice of the Constitution Court of South Africa. He is currently serving as the
Inspecting Judge for the Judicial Inspectorate for Correctional Services. He is greatly indebted to his law clerk, Rebecca Gore, for extensive help in drafting and referencing this article. The text of this article was first delivered at the University of Cape Town as the 2019 Bennie Rabinowitz Lecture, which was held on 11 September 2019. The author wishes also to acknowledge Bennie Rabinowitz, who has
personified the spirit of generous inquiry, social commitment personified the spirit of generous inquiry, social commitm
and deep personal humility, for his unfalling warmth and support over the years for various heterodox causes and views.

E Cameron, Imprisoning the nation: minimum sentences in South Africa, Paper presented at Dean's Distinguished Lecture at the University of the Western Cape, 19 October 2017, www.concourt.org.za/images/phocadownload/justice cameron/UWC-Deans-distinguished-lecture-19-Octob 7-Minimum-Sentences.pd.

3 Department of Correctional Services, Draft White Paper on

Department of Correctional Services, Draft White Paper on

A Dissel and S Ellis, Reform and stasis: Transformation

Prior to May 2014, the Department of Correctional Services named thate department and the Justice Department was named the Depart
Development.

South African Human Rights Commission, Report of The files/Reports/The\%20Nationals\%20Prisons\%20Project\%20 of\%20SAHRC. 1998.pdt.

8 South African Human Rights Commission, Report of the national Prisons Project, 3.

9 Section 35(2)(e) of the Bill of Rights.

10 D Van Zyl Smit, Swimming against the tide: Controlling the prison population in the new South Africa in $W$ Dixon and $E$ van der Spuy (eds) Justice Gained? Crime and Crime Control in South Africa's Transition, Cape Town: UCT Press, 2004. C De Kock, A Kriegler and M Shaw, A citizen's guide to crime statistics: 1994-2015, Centre of Criminology, 2015

M Schönteich and A Louw, Crime trends in South Africa 1985-1998, Centre for the Study of Violence and

3 P Burton, A du Plessis, T Leggett and A Louw, National victims of crime survey South Africa 2003, ISS Monograph

14 D Van Zyl Smit, Swimming against the tide, 238

15 J Redpath, Unsustainable and unjust: Criminal justice policy and remand detention since 1994, South African Crime

D Van Zyl Smit, Swimming against the tide, 232.

17 S Tshwete, Remarks at a Parliamentary Briefing, 28 June 1999. Quoted in C Ballard and R Subramanian, Lessons from the past: remand detention and pre-trial services, South Arrcan Crime Quarterly, 2013, 17-8, https://159/2413-3108/2013/voil44a816.

18 Criminal Procedure Second Amendment Act 75 of 1995, which came into operation on 21 September 1995 and which came into operation on 1 August 1998.

9 Sections 4 and 9 of the Prevention of Organised Crime Act 121 of 1998
20 A Dissel, Tracking transformation in South African prisons, Track Two, 11, 2002

21 L Muntingh, An analytical study of South African prison ( Cape, 2012, 385.

22 Department of Correctional Services, Jali Commission of nquiry into alleged incidents of corruption, maladministrat vervices, 2005, 444. Services, 2005, 444.

24 Sv Gibson 1974 (4) SA 478 (A) at 481H-482B

25 S V Mpetha 1985 (3) SA 702 (A) at 706H (Corbett JA) and 710D-E (van Heerden JA, who as counsel eleven years was the five-year minimum sentence under the Terrorism Act 83 of 1967

26 In S v Vilakazi 2012 (6) SA 353 (SCA) at para 10, Nugent JA pointed out that a sophisticated system to construct
guidelines to secure consistency in sentencing was subsequently recommended by the South African Law Reform Commission (SALRC) in December 2000 - a recommendation made after a comprehensive review of sentencing practice in this country and abroad. But the which 'would have been welcome to many iudges who face the difficult task of sentencing', was never introduced. Instead, the 'temporary regime' in the 1997 statute became permanent.

27 Library of Congress, Sentencing guidelines: South Africa, www.loc.gov/law/help/sentencing-guidelines/southafrica. php.

28 South African Law Commission (SALRC), Discussion Paper 91: Project 82, 16

29 STerblanche, Mandatory and minimum sentences: Considering s 51 of the Criminal Law Amendment Act 1997, gives a full exposition of the himport and language of amending statute.

30 section $51(5)$.

30 Section $51(5)$

12 Section 51(4).

33 Van Zyl Smit, Swimming against the tide, 203

34 Hansard, Debates of the National Assembly 16 November

35 Section 53 of the Criminal Law Amendment Act of 199 states: 'Sections 51 [minimum sentences for certain serious case to have effect ffter the to siry of two years fom the commencement of this Act'.

36 Act 38 of 2007 .

37 S Terblanche, Sentencing guidelines for South Africa: Lessons from elsewhere, South African Law Journal, 120:4 2003, 858, https://heinonline.org/HOL/P?h=hein.journals/ soaf1208i $=868$.

38 Section 51(3)(a)

39 SALRC, Discussion Paper, xvii.

40 See 'Submission to the Minister of Justice and Constitution Development in response to the evaluation of the Criminal Law Amendment Act 105 of 1997 ' prepared by The Wester Cape Consortium of Violence Against Women, 2005.

Department of Cort

42 Department of Correctional Services, Annual Report 1995, 5 .

43 Established under Chapters IX and $X$ of the Correctional Services Act 111 of 1998
44 Terblanche, Sentencing guidelines for South Africa. yane [1995] ZACC 3; 1995 (6) BCLR 665; 1995 (3) SA 391 (CC)

46 South Africa History Onine, The South African Constitutiona Court abolishes the death penalty, 1995, www.sahistory.org. zardated-event/sa-constitutional-court-abolishes-deathpenalty- 0 .

47 Judicial Inspectorate for Correctional Services, Annual report

48 R Jules-Marquet, The State of South African Prisons, NICRO Public Education Series 1, 2014, www.nicro.org.zal wp-content/piloads/2014/04/Public-Education-Paper-The-

49 See J Steinberg, Nongoloza's children: Western Cape prison gangs during and after Apartheid, Centre for the Study of in South Africa: A description, South African Journal of Sociology, 19:2, 1988, https://www.doi.org/10.1080/025801 44.1988.10558376.

50 E Cameron, Report: Pollsmoor Correctional Centre - Remand Centre and Women's Centre, 2015, www. constitutionalcourt.org.za/site/PrisonVisitis/Cameron/ Pollsmoor-Prison-Report-23-Aph-2

51 Judicial Inspectorate of Prisons, Annual Report for the Period 2017-2017.

53 Without an official estimate there seems to be a discrepancy in the exact recidivism rates but all these rates are particulary

54 Inspecting Judge from 1 April 2000 - 31 March 2006. Judicial Inspectorate of Prisons, Annual Report for the Period
2003-2004, 21

56 E Cameron, Imprisoning the nation: minimum sentences in South Africa has been cited in EN Keehn and A Nevin,

South African litigation to address HIV and tuberculosis in prisons, Health and Human Rights, 20:1, 2018, https://wwm. prisons, Heatth and Human Rights, $20.1,2018$.
ncbi.nim.nih.gov/pmo/articles/PMC6039737/.

57 E Hinton, LS Henderson and C Reed, An unjust burden: The disparate treatment of black Americans in the criminal justice system, Vera Institute of Justice, 2018, www.theguardian.
com/us-news/2016/iun/18/mass-incarceration-blackcom/us-news/2016/jun/18/mass-incarceration-blackamericans-higher-rates-disparities-report. Also see MW
Bennett, How mandatory minimum forces me to send more than 1000 nonviolent drug offenders to federat prison more than 1000 nonviolent drug offenders to federal prison, The minimums-forced-me-send-more-1000-nonviolent-drugoffenders-federal-pri/.

58 See further http://detentionjusticeforum.org.za/.

Note, during the period 1994-2011 violent crime dipped and then started rising again. See United Nations Office on Drugs and Crime, Global study on homicide: Homicide trends, patterns and criminal justice responses, 2019, www.
org/documents/data-and-analysis/gsh/Booklet2.pdf.

60 C Bhengu, Thousands sign petition calling for penalty on crimes against women, TimesLive (3 September 2019), www.timeslive.co.za/news/south-africa/2019-09-03thousands-sign-petition-calling-for-death-penalty-on-crimes-
against-women/; J Gerber. Death penalty referendum: ATM wants Parliament, Ramaphosa to give SA a say N News24 September 2019), www.news24.com/SouthAfrica/News/ death-penalty-referendum-atm-wants-parliamentramaphosa-to-give-sa-a-say-20190904.

61 Stats SA, Youth unemployment rate increases in Q1: 2019, 2019, www.statssa.gov.za/?p=12121 
62 GS Becker, Crime and punishment: An economic approach, Journal of Political Economy, 1968, https://www.jstor.org/ stable/1830482.

63 Africa Check, Factsheet: the state of South Africa's prisons, 2017, https://africacheck.org/factsheets/factsheet-the-stateof-south-africas-prisons/

64 Muntingh, An analytical study of South African prison reform after 1994, 356.

65 G Silber and N Geffen, Race, class and violent crime in South Africa: Dispelling the 'Huntley thesis', South African Crime Quarterly, 41, 2009, https://doi.org/10.17159/2413-

66 Democratic Alliance v President of South Africa [2012] ZACC 24, 2012 (12) BCLR 1297 (CC), 2013 (I) SA 248 (CC) (5 as National Director of Public Prosecutions: Corruption Watch NPC $v$ President of the Republic of South Afric Nxasana v Corruption Watch NPC [2018] ZACC 23; 2018 (10) BCLR 1179 (CC); 2018 (2) SACR 442 (CC) (13 August 2018), nullifying the appointment of Shaun Abrahams.

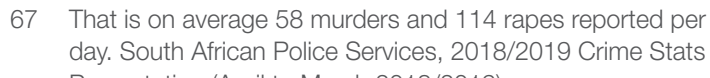
Presentation (April to March 2018/2019), www.saps.gov.za/ services/april-march_2018_19_long_version_presentation. pdf.

$68 \mathrm{~J}$ Omar, Violence against women: Law is not the solution, Daily Maverick, 2019, www.dailymaverick.co.za/ (a)

69 [2018] ZACC 30; 2018 (10) BCLR 1220 (CC); 2018 (6) SA

70 The Constitutional Court quoted with apparent endorsement (in para 34) the conclusion of the High Court that 'The
evidence, holistically read together with the arguments presented to this court, suggests that the blunt instrument of the criminal law as employed in the impugned legislation is disproportionate to the harms that the legislation seeks to curb insofar as the personal use and consumption of cannabis is concerned" (High Court judgment para 108, www.safli.iorg/za/cases/ZAWCHC/2017/30.htmil.

71 Open Society Foundations, Why we need drug policy reform 2019, www.opensocietyfoundations. org/explainers/ why-we-need-drug-policy-reform

72 The mandatory minimum sentencing regime flowed from recommendations by two committees established by the Minister of Justice. One recommended the establishment of
a Sentencing Council.

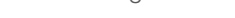

Vilakazi. Also see Minnesota Sentencing Guidelines, which

74 See Loza v Police Station Commander, Durbanville 1964 (2) ff 1963 and

75 Protects against deprivation of freedom arbitrarily and without just cause and to be detained without trial.

76 Affords every person arrested the right to be released from detention If the interests of justice permit, subject to

Ballard and Subramanian, Lessons from the past; J Sarkin, E Steyn, D van ZyI Smit and R Paschke, The Constitutiona Journal on Human Rights, 16:2, 2000, https://doi.org/10.108 0/02587203.2000.11827597.

78 S Mkhwanazi, Move to tighten SA's bail laws, IOL (6 March 2017), www.iol.co.za/news/move-to-tighten-sas-baillaws-8065927.
79 Parliamentary Monitoring Group, Justice, Crime Prevention and Secunty (JCPS) Post-SONA Cluster Media Biefing, 5 March 2017, hitps.//Pmg.org.za/briefing/24080/.

80 SE Van der Merwe, Bail and other forms of release, in JJ Joubert (ed) Criminal Procedure Handbook 12 ed, Cape

81 Dlamini.

82 In S v Acheson 1991 (2) SA $805(\mathrm{Nm})$ at 822A-B 'an accused cannot be kept in detention pending his trial as a torm of anticipa bery punishment. The presumption of the law Cout'.

83 E Cameron, Visit to Johannesburg Correctional Centre

$84 \mathrm{~N}$ De Ruiter and K Hardy, Study on the use of bail in South

85 Section $602 \mathrm{~B}($ a) provides that if it is in the interests of justice a sum of money is to be considered as a condition of bail a court must hold a separate inquiry into the ability of the accused to pay the sum. Section 602B(b) authorises to court to consider bail conditions that do not include monetary amounts.

86 Conducted by the South African Institute of Race Relations (IRR). This initiative could decease prison population immediately by $5 \%$.

87 See South African Institute of Race Relations, IRR urges Wwakers to act on 'prisoners of poverty' in South Africa's jails, 2016, https://irr.org.za/media/media-releases/ irr-urges-lawmakers-to-aft-on-2019-jails. Also see van de Merwe, Bail and other forms of release 221.

88 See Annexure A of Cameron's 'Visit to Johannesburg

89 See Judicial Inspectorate of Correctional Services Report

However, requirements must be met: it must be the offender's first offence, the offence must not be serious, the offence(s) as described in the summany of the forts the rights of the offender must have been explained to him or her and the offender must agree to the terms of diversion. Also see S Maimane, Restorative justice for adult offenders South Africa: A comparative study with Canada, New Zealand, England and Whes,

1 Article 135(2) of the Armenian Criminal Code of Procedure against the accused only for crimes punishable by mose the one-year imprisonment or when there are sufficient grounds to assume that the accused can commit actions mentioned in the first part of the present article'.

92 De Ruiter and Hardy, Study on the use of bail in South Africa. Ibid. Pre-trial senvices have also shown some success in the United States; when rendered effectively unnecessary
remand detention is minimized, see Human Rights Watch, The price of freedom: Bail and pre-trial detention of low income nonfelony defendants in New York Citty, 2010, whw. 94 Vera Institute of Justice.

95 De Ruiter and Hardy, Study on the use of bail in South Africa. See also M Schonteich, Making courts work: A review of the IJS court centre in Port Elizabeth, ISS Monograph 75, 2002. 96 De Ruiter and Hardy, Study on the use of bail in South Africa. 97 SALRC, 22.
98 Duty solicitors can also be found in other jurisdictions such as, England, Wales, Canada, Australia and New Zealand.

Open Society Justice Initiative, Lawyer at the police How REPLACE provides legal aid in Nigeria, (March 2015) www.justiceinitiative.org/publications/lawyer-police-stationdoor-how-replace-provides-legal-aid-nigenta

100 De Ruiter and Hardy, Study on the use of bail in South Africa. 101 [2019] ZACC 32; 2019 JDR 1494 (CC).

102 JJ Kerbs and KM Jolley, A Commentary on age segregation for older prisoners: Philosophical and pragmatic considerations for correctional systems, Criminal Justice Review, 34:1, 2009, https:///doi.

103 PC Perkins and E Seawell, Human dignity and evolving Standards of decency: Disciplinary segregation of inmates in when confinement of six Pretoria prisoners in the spotlight, (July 16 2015), www.enca.com/southafrica/solitary-confinement-sixpretoria-prisoners-spotlight

104 SALRC.

105 SALRC: sentences must consider the interests of victims, victim impact statements, informing victims of the release or sentence of har acoused and other mechanisms.

106 De Ruiter and Hardy, Study on the use of bail in South Africa.
107 lbid.

Jer violence in SA - ISS, News 24 (12 September 2019), www. isnt-enoum/SouthAfica/News/crime-stats-policing-alon-

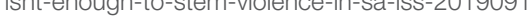

109 E Cameron, Report: Devon Correctional Centre, Modderbe Management Area, (visit took place 27 June 2017), www
concourt.org.za/images/phocadownload/prison visits/ camernon/Prisons-Devon-Correctional-Contro-November2017-Reportx17-tracked-input.pdf.

110 L Ensor, Prison overcrowding a 'disturbing' problem for Government, (17 July 2019) Business Day, www. overcrowding-a-disturbing-problem-for-government/

$111 \mathrm{~K}$ Somdyala, Death penalty will not deal with femicide and violence against women and children - Justice Dept, News24 (4 September 2019), www.news24.com/ SouthAfrica/News/death-penalty-will-not-deal-with-femicide and-violence-aga
dept-20190904

112 See above Lee, Prince, Phaahla and De Klerk as well as Lee BCLR 129 (CC); 2013 (2) SA 144 (CC) and Phaahla v Minister of Justice and Correctional Services [2019] ZACC 18; 2019 (2) SACR 88 (CC); 2019 (7) BCLR 795 (CC).

113 Business Day, Crime data shows SA at war with itself, 13 September 2019. 